DOI: 10.34015/2523-4552.2019.2.07

УдК 343.81

Денисова Т. А.,

доктор юридичних наук, професор,

заслужений юрист України,

член Президії ГО «Всеукраїнська асоціація

кримінального права»

ORCID ID: 0000-0003-4346-4502

\title{
ЧИ ПОТРІБНА МОДЕРНІЗАЦІЯ КРИМІНАЛЬНО-ВИКОНАВЧОГО ЗАКОНОДАВСТВА?
}

\begin{abstract}
Я не думаю, що в республіці можна знайти щонебудь більш негідне, ніж коли закон приймають і його не дотримуються, і вже тим більще, коли закону не дотримується сам законодавець.
\end{abstract}

Н. Макіавеллі

У статті визначено проблеми, що вказують на необхідність модернізації кримінально-виконавчого законодавства у зв'язку із запровадженням масштабної правової реформи. Розглянуто питання кримінально-правової та кримінально-виконавчої політики. Указано на розгалужений арсенал наявних заходів кримінально-правового та кримінально-виконавчого впливу на осіб, які вчинили злочин. Визначено проблеми, що впливають на якість кримінально-виконавчого законодавства.

Ключові слова: реалізація покарання; кримінальне законодавство; кримінально-виконавче законодавство; модернізація; кримінально-виконавча служба; пробація.

В статье определены проблемы, указывающие на необходимость модернизации уголовно-исполнительного законодательства в связи с введением масштабной правовой реформы. Рассмотрены вопросы уголовно-правовой и уголовно-исполнительной политики. Указано на имеющийся разветвленный арсенал существующих мер уголовно-правового и уголовно-исполнительного воздействия на лиц, совершивших преступление. Определены проблемы, влияющие на качество уголовно-исполнительного законодательства.

Ключевые слова: реализация наказания; уголовное законодательство; уголовно-исполнительное законодательство; уголовно-исполнительная служба; пробация.

Постановка проблеми. Розвиток суспільства неминуче має бути пов'язаний із увагою до людини, iї прав, свобод, внутрішнього світу та проблем життя. Шлях, який торує наша держава до стандартів Європейського Співтовариства, показав, що в царині кримінально-правових та кримінально-виконавчих відносин багато залишається того, що че- 
кає змін, і ці зміни повинні стати тестом гуманістичного розвитку суспільства незалежної України.

Сучасна кримінально-правова та кримінально-виконавча політика має доволі розгалужений арсенал заходів кримінально-правового та кримінально-виконавчого впливу на осіб, які вчинили злочин, адже поряд із покараннями, що пов'язані 3 позбавленням волі, кримінальним законом передбачені й інші, альтернативні види, а також указані підстави звільнення від кримінальної відповідальності, від покарання, від кримінального покарання 3 випробуванням тощо. Однак плин часу диктує нагальну потребу не просто внесення змін та доповнень до кримінально-виконавчого законодавства, а необхідність його повного переформатування.

Усе вказане підкреслює актуальність питання про необхідність якісної модернізації кримінальновиконавчого законодавства.

Аналіз останніх досліджень і публікацій. На теренах незалежної України над проблемами кримінально-виконавчого права досить плідно працюють такі науковці, як К. А. Автухов, Л. В. Багрій-Шахматов, Є. Ю. Бараш, І. Г. Богатирьов, С. Ф. Денисов, О. М. Джужа, . М. Дрьомін, О. Г. Колб, І. М. Копотун, О. Г. Крикушенко, О. В. Лисодєд, М. П. Мелентьєв, В. М. Пальченкова, М. С. Пузирьов, Г.О.Радов, А.Х. Степанюк, В. М. Трубников, Ю. В. Шинкарьов, I. С. Яковець та ін. Однак, незважаючи на значну кількість наукових праць, питання реформування кримінальновиконавчого законодавства привертають до себе постійну увагу.

Постановка завдання. Дослідити потребу в модернізації кримі- нально-виконавчого законодавства та показати внесок і роль науковців та персоналу Державної кримінально-виконавчої служби (далі - ДКВС) у проведенні реформ.

Виклад основного матеріалу. Сучасне кримінальне та кримінальновиконавче законодавство України все ще перебуває на етапі свого формування, про що свідчать численні кардинальні зміни, що відбувалися протягом дії Кримінального (далі - КК) та Кримінально-виконавчого (далі КВК) кодексів, а також у механізмі правового регулювання останніх років.

Відповідно до вимог кримінальної політики формується коло кримінально-караних діянь, установлюється вид і розмір санкцій та порядок застосування покарань. Це, передусім, визначення основних напрямків політики держави в питаннях призначення, виконання і ефективності покарань, функцій покарання, співвідношення сутності, змісту, завдань та мети покарання, застосування альтернативних позбавленню волі видів покарань. На сьогодні при формуванні кримінальної політики одним 3 важливих завдань є пошук оптимального балансу у використанні методів переконання, заохочення та примусу для того, щоб покарання, зокрема, відповідало тяжкості злочину.

Закономірно, що підвищена соціальна небезпека злочинів відбивається на призначенні суворого покарання у виді позбавлення волі на тривалі терміни. Суспільство таким чином захищає себе шляхом застосування суворих кримінально-правових санкцій стосовно особи, яка вчинила злочин.

3 огляду на значне посилення злочинності не тільки в масштабах 
нашої країни, а й у транснаціональному вимірі, усунення колізій, прогалин та вирішення інших проблем політики України у сфері реалізації покарань $є$ вельми актуальним завданням. Сучасність вимагає нових поглядів на такий важливий інститут кримінального права, як покарання, без переосмислення сутності якого доволі складно вирішувати ті проблеми, які стоять перед українською спільнотою в галузі кримінального права. Треба правильно визначити коло кримінально караних діянь; установлювати вид i розмір найбільш оптимальних санкцій, які б відповідали ступеню суспільної небезпеки вчиненого злочину та особі злочинця; обгрунтовувати підходи до диференціації та індивідуалізації покарань; реалізовувати повною мірою принцип економії кримінальноправової репресії. У процесі реформування КК України необхідно враховувати пропозиції про призначення покарання шляхом його раціоналізації, що передбачає як гуманізацію законодавства, так і посилення відповідальності за вчинення окремих злочинів. Варто підтримати позицію науковців, за якою гуманізація системи призначення покарання в Україні $є$ доцільною лише стосовно осіб, яких раніше не було засуджено за вчинення умисних злочинних діянь; стосовно деяких категорій осіб, які вчинили тяжкі чи особливо тяжкі злочини, навпаки, необхідно посилювати кримінальну репресію.

Певний час питання кримінального покарання, у тому числі його застосування, були предметом кримінального права. У міру ускладнення системи кримінальних покарань, її мети та завдань, появи нових форм та видів їх виконання, нових органів, що виконують покарання, з кримінального права як самостійна почала виділятися нова галузь, яка в різних країнах отримала певну назву, а саме: пенологія, пенітенціарне право, виправно-трудове право, кримінально-виконавче право та інші.

Сьогодні загальновідомим $\epsilon$ ступінь впливу кримінального права і законодавства на сучасне кримінально-виконавче право й законодавство. Звісно, що кримінальновиконавче право й законодавство $\epsilon$ похідним від кримінального. До того ж загальновизнано вважати, що значним такий вплив простежується при реалізації покарання. Норми КВК виконують, так би мовити, допоміжну роль у реалізації інституту покарання, визначену в матеріальному праві. Як постійно наголошує більшість науковців, кримінальне право, як i кримінальне законодавство, $\epsilon$ базовим стосовно кримінальновиконавчого, а визначення в КК поняття, завдань, мети та видів покарань, мають вирішальне значення для КВК $[1$, с. $130 ; 2$, с. $16 ; 3$, с. $5 ; 4$, с. $18 ; 5$, с. 210$]$.

Таким чином, якщо прийшов час змін до кримінального законодавства, це неодмінно потягне кардинальні, а не косметичні, зміни кримінально-виконавчого законодавства. Тому необхідно вести мову не про його оновлення шляхом унесення змін та доповнень, а про модернізацію повним переформатуванням. Модернізація (англ. modern - сучасний, передовий) - це оновлення КВК шляхом приведення його сутності та змісту у відповідність до нових потреб, що виникають із реформуванням кримінального законодавства.

7 серпня 2019 року Президент України видав Указ № 584/2019, 
яким затвердив Положення про Комісію з питань правової реформи [6] (далі - Комісія). Відповідно до пункту 28 частини першої статті $106 \mathrm{Koн-}$ ституції України Президент постановив затвердити Положення про Комісію та її персональний склад. Керуючись демократичними стандартами та найкращими світовими практиками, зокрема держав - членів Європейського Союзу, основним завданням Комісії визначається «сприяння подальшому розвитку правової системи України на основі конституційних принципів верховенства права, пріоритетності прав і свобод людини і громадянина з урахуванням міжнародних зобов'язань України».

Серед новоутворених робочих груп Комісії цікавим $є$ те, що є потужний склад груп розвитку кримінального права та реформування кримінальної юстиції. Це, зокрема, високоповажні та знані фахівці з кримінального та кримінального процесуального права. Формування складу робочих груп Комісії здійснювалося відповідно до покладених завдань, у тому числі щодо кримінальноправового та процесуального напрямів, - це підготовка та узагальнення пропозицій до законодавства про кримінальну відповідальність та кримінального процесуального законодавства. На превеликий жаль, жодного фахівця 3 кримінальновиконавчого права у складі цих груп немає, як немає згадки про необхідність реформування кримінальновиконавчого законодавства.

Переформатування КВК України повинно відбуватися за декількома різновекторними напрямами. На окремих з них доцільно зупинитися вже зараз.
Якість закону та його превентивний характер. Ефективність превентивних можливостей кримінального та кримінально-виконавчого законів як дієвих засобів у сфері запобігання злочинам постійно підкреслюється законодавцем, науковцями та практиками. У процесі підготовки та прийняття нових КК та КВК України необхідно звернути увагу на вживану термінологію та правильне тлумачення норм закону. Також варто оцінити, завдяки статистичним даним, ефективність реалізації тих завдань, що визначені законодавцем. Передусім, це охорона від злочинних посягань найбільш важливих благ, життя, здоров'я та безпеки людини, забезпечення миру тощо. Адже прийняття неякісного закону не гарантує його якісного виконання. До того ж це породжує зневіру до закону в громадян, провокує нігілістичні настрої суспільства.

Реалізація покарань за кримінальні проступки. Як відомо, свого часу пропозиція поділяти суспільно небезпечні діяння на злочини та кримінальні проступки викликала жваві обговорення, оскільки значна кількість запропонованих положень була суперечливою за змістом, що викликало низку проблем. Сьогодні позиція щодо впровадження кримінальних проступків міцно зайняла своє право на існування. Як видається, новий КК України обов'язково позитивно вирішить це питання, оскільки існування кримінальних проступків вже закріплено в Кримінальному процесуальному кодексі (далі - КПК) України. Вбачається, що в новому КВК України також повинні знайти відповіді питання, зокрема, як буде реалізована система покарань за кримінальні проступки, на які органи й установи 
буде покладено виконання цих покарань, який порядок і умови виконання цих покарань тощо.

Реалізація кримінальної відповідальності юридичних осіб. Варто нагадати, що інститут відповідальності юридичних осіб уведений у кримінальне законодавство у 2013 р. 3 подальшими змінами у 2014 та 2015 роках і внесенням до КК України розділу XIV-1 «Заходи кримінально-правового характеру щодо юридичних осіб» [7]. У статті 96-6 КК України - «Види заходів кримінально-правового характеру, що застосовуються до юридичних осіб» - зазначено, які основні та додаткові заходи кримінально-правового характеру можуть бути застосовані до юридичних осіб: 1) штраф; 2) конфіскація майна; 3) ліквідація. У частині другій цієї статті уточнено, що при «... застосуванні заходів кримінальноправового характеру юридична особа зобов'язана відшкодувати нанесені збитки та шкоду в повному обсязі, а також розмір отриманої неправомірної вигоди, яка отримана або могла бути отримана юридичною особою». Характерно, що в законі досить детально роз'яснено повноваження представника юридичної особи, щодо якої здійснюється провадження, проте незначну увагу звернуто на порядок, умови виконання вказаних заходів кримінально-правового характеру та органи, на які покладається їх виконання. Мабуть, складно виконати закон, коли немає чіткого визначення порядку й умов його виконання.

Інститут розгляду цивільного позову. Практично кожний злочин породжує не тільки кримінальноправові, а й цивільно-правові наслідки у виді заподіяння шкоди майно- вим правам та законним інтересам фізичних або юридичних осіб. В Україні склалася усталена практика, що інститут розгляду цивільного позову разом з кримінальною справою / кримінальним провадженням $€$ невіддільним елементом кримінального процесу, а сам цивільний позов має враховуватися при вирішенні завдань кримінального судочинства. Сьогодні відмова в позові в порядку цивільного судочинства позбавляє позивача права пред'являти той же позов у кримінальному провадженні, а отже, злочинець не несе матеріальної і моральної відповідальності, а держава не в змозі захистити інтереси потерпілої особи. У зв'язку з цим виникає проблема щодо примусового відшкодування заподіяної злочином шкоди. Нагадаємо, що за законодавством багатьох держав, зокрема Аргентини, Австрії, Іспанії, Італії, Польщі, ФРН, з метою захисту прав потерпілих питання кримінально-правової реституції (примусове відшкодування потерпілому заподіяної злочином матеріальної та моральної шкоди) регламентуються кримінальним законодавством. Так, наприклад, у КК Польщі обов'язок відшкодування потерпілому заподіяної злочином шкоди встановлений $\mathrm{y}$ главі V «Кримінально-правові заходи», пункт 5 статті 39 якої передбачає, що одним 3 таких $є$ обов'язок відшкодувати шкоду шляхом виплати грошової компенсації певного розміру. Поширена практика спрямування коштів від штрафів до спеціального фонду компенсації шкоди жертвам злочинів, як показує практика, також вкрай неефективна через бюрократичну тяганину, не меншу від судової. Вбачається, що розроблення цього питання було би 
перспективним. За нинішніх умов потребують широкого застосування також санкції, де вказано альтернативи позбавленню волі, але не слід забувати про збалансованість вини та кари, коли остання була б адекватною і достатньою, задовольняла певною мірою потерпілого та винного у вчиненні злочину, суспільство й державу.

Виправлення та ресоціалізація засуджених як мета покарання. Не підтримуючи та не спростовуючи наявні теорії щодо виправних можливостей покарання, лише підкреслю, що цілі покарання $\epsilon$ не тільки кінцеві (на чому наголошує законодавець), а й проміжні. До того ж частина цілей $\epsilon$ малодосяжними, особливо в умовах жорсткої ізоляції засудженого від суспільства.

Як видається, виправний процес (виховні заходи, соціальні та виправні програми тощо) повинен здійснювати спеціальний персонал, відібраний на конкурсній основі. Він повинен бути глибоко обізнаний в основах загальної та юридичної психології, педагогіки, соціальній сфері, виконувати обов'язки за контрактом чи трудовою угодою. Діяльність із виправлення та ресоціалізація засудженого повинна стати його основним завданням, що необхідно врахувати у новому КВК України.

Функціонування приватних пенітенціарних установ. Попри дискусійність цього питання ми повинні діяти на випередження. Адже як свого часу наголошувала Дж. Митфорд, незважаючи на проведення низки тюремних реформ, нові споруди виправних закладів, як і нові пенітенціарні теорії, виявилися неспроможними змінити старий «тюремний дух», який породжує деградацію та спустошення особистості [8, с. 1920]. Як видається, це питання перетинається із попереднім.

Як змінити старий «тюремний дух» в установах виконання покарання, які діють сьогодні? Може, необхідно розглянути як позитивні моменти, так і недоліки функціонування приватних пенітенціарних установ, шляхом дослідження зарубіжного досвіду, аналізу статистичних даних щодо категорії осіб, які могли б утримуватись у вказаних установах, вивчення думки фахівців у сфері виконання покарань, представників органів влади, учених та узагальнення їх пропозицій. Про можливості запровадження приватних установ неодноразово висловлювався заступник міністра юстиції Д. В. Чернишов, але при цьому акцентував увагу на законодавчому регламентуванні питання: «Природно, що в такому випадку існують законодавчі правила, що регламентують режим утримання ув'язнених у приватних закладах, зміст виправних заходів тощо» [9].

Вплив іншого галузевого законодавства на кримінально-виконавче законодавство. Хоча кримінальновиконавче законодавство тяжіє до кримінального, однак вплив на кримінально-виконавче право й законодавство інших галузей, у тому числі кримінального процесуального, трудового, цивільного, конституційного, сімейного права, $є$ значним. Так, за період існування України як незалежної держави права і свободи засуджених, особливо до позбавлення волі, істотно розширено, що значно наблизило умови утримання громадян цієї категорії до міжнародних стандартів. Прикладом цього може бути частина друга статті 7 КВК 
України - «Основи правового статусу засуджених», де визначено, яким чином закріплюються і гарантуються політичні, загальногромадянські та інші правові питання при відбуванні покарання, а саме: «Засуджені користуються усіма правами людини і громадянина, за винятком обмежень, визначених законами України, цим Кодексом і встановлених вироком суду»[10]. Так, якщо правове становище осіб, які відбувають покарання, не дозволяє їм особисто брати участь у вирішенні тих чи інших питань (брати участь у цивільноправових угодах, оплачувати комунальні платежі, вирішувати проблеми стягнення аліментів, оскаржувати трудові взаємовідносини і ін.), засуджені можуть діяти через свого представника. Однак існує низка проблем, що можуть вирішуватися неоднозначно. Прикладом таких $\epsilon$ полеміка стосовно конституційного права на працю й проблеми щодо його реалізації у кримінальновиконавчому та кримінальному процесуальному праві, а також реалізація засудженим свого виборчого права тощо.

Основні права засуджених регламентуються статтею 8 КВК України. Одне з них - право на працю. Справді, засуджені мають право на працю, гарантовану оплату праці, надання відпустки, право на соціальне забезпечення, у тому числі й на отримання пенсій, відповідно до законів України. Необхідно підкреслити, що зараз засудженим гарантується право на працю, але це не $\epsilon$ їх обов'язком. Проте матеріальну підставу викладено в частині другій статті 81 КК України так: засуджений повинен довести своє виправлення сумлінною поведінкою і ставленням до праці. Тобто для умовно-дострокового звільнення засуджений повинен працювати. Підтвердженням цього $€$ й норма КПК України.

Інший приклад: засуджені мають право голосу в період проведення виборів. Однак особи, які відбувають покарання у виді позбавлення волі на певний строк, не мають права в період проведення виборів до органів державної влади та місцевого самоврядування проводити зустрічі з виборцями; не допускається проведення мітингів, походів і демонстрацій; обмежено право на свободу об'єднання в політичні партії та громадські організації та інші.

Забезпечувати дотримання вимог Конституції України, інших законів - це обов'язок усіх органів держави і посадових осіб, громадських організацій і громадян [11, с. 4]. Визначивши це, наша держава приєдналася до європейського і світового бачення цієї проблеми, намагається створити відповідні передумови для iї вирішення у всіх сферах взаємин особи і суспільства, громадянина i держави. Таким чином, ще раз виникає необхідність приведення норм КВК України у відповідність до Основного Закону України та галузевого законодавства.

Усе вказане лише зміцнює переконання в необхідності модернізації кримінально-виконавчого законодавства. Науковцям і практичним працівникам Державної кримінально-виконавчої служби таку роботу необхідно починати терміново, паралельно з обговоренням нового КК України.

Висновки. Зрештою, необхідно нагадати, що ключові проблеми «злочин і покарання», - завжди були і залишаються постійним предметом 
досліджень у філософії та соціології права, кримінальному, кримінальновиконавчому праві, кримінології та ін. Однак накопичені знання та результати проведених наукових досліджень вимагають нових підходів, заснованих на сучасних досягненнях науки кримінального, кримінальновиконавчого права та кримінології. Численні наукові праці дають можливість узагальнити отримані знання, оцінити правильність або помилковість підходів до призначення i виконання покарань, створити сприятливі умови для реформування системи покарань i їх застосування, а також сприяти якісному оновленню всієї системи органів і установ виконання покарань.

Незважаючи на спірність окремих питань, про що було сказано, ці знання сприяють розвитку оптимальної системи виконання покарань, відповідають інтересам цивілізації, загальновизнаним людським цінностям, громадської безпеки та нормам моралі.

Той, хто хоча б один раз відбував покарання в місцях позбавлення волі, не відчуває страху перед новим можливим засудженням. Для таких осіб стають звичними і специфічне оточення, і традиції, і загальна система відбування покарання. Тому в стратегії реформування кримінально-виконавчої системи повинні поновому розглядатися ідеї каяття - як можливості виправлення, каяття за вчинені суспільно небезпечні діяння, духовного відродження, можливості заслужити пробачення в Бога, сім'ї, близьких людей і суспільства загалом.

3 огляду на комплексність викладених проблем, змін ідеологічної та практичної парадигм у сучасних умовах України виникла необхідність у проведенні модернізації КВК України. Ще раз необхідно підкреслити, що така робота повинна бути розпочата одночасно 3 переформатуванням КК України. Однак цей крок не може бути успішно реалізований, якщо він не передбачає участі наукового потенціалу, інститутів громадянського суспільства, максимальної відкритості, а також значного матеріального та інформаційного забезпечення.

Виклад окреслених питань має проблемний характер, оскільки реформування кримінального законодавства вже розпочалося, а кримінально-виконавчого - перебуває лише на початковій стадії. Крім того, слід ураховувати, що сучасна Державна кримінально-виконавча служба України також знаходиться на стадії реформування. Це, без сумніву, вплине на роботу над новим КВК України. Тому окремі положення сформульовано в постановочному порядку - як наукові гіпотези, основою яких $є$ дослідження проблем, пов'язаних 3 властивостями і реалізацією покарань, особливостями досягнення цілей і відновленням особистості осіб, які зазнали покарання. Ці питання мають особливу складність і вимагають різнобічних методологічних підходів, систематизованого і послідовного вивчення.

\section{Список використаних джерел}

1. Утевский Б. С. Вопросы теории исправительно-трудового права и практика его применения. Советское государство и право. 1957. № 12. С. 129-132. 
2. Ткачевский Ю. М. Соотношение уголовного и уголовно-исполнительного законодательства. Вестник Московского университета. Серия «Право». 1998. № 2. C. $12-24$.

3. Кримінально-виконавче право України: Підручник для студентів юридичних спеціальностей вищих навчальних закладів / За ред. проф. А. Х. Степанюка. Харків : Право, 2005. 256 с.

4. Уголовно-исполнительное право: Курс лекций. Отв. ред. док. юрид. наук, проф. А. А. Толкаченко. Санкт-Петербург : Изд-во «Юрид. центр. Пресс», 2004. 505 с.

5. Денисова Т.А. Кримінальне покарання: завдання і функції, практика застосування. Правова система України: історія, стан та перспективи: у 5 т. Т. 5 : Кримінально-правові науки. Актуальні проблеми боротьби зі злочинністю в Україні /За заг. ред. В. В. Сташиса. Харків : Право, 2008. С. 208-219.

6. Положення про Комісію з питань правової реформи: Указ Президента України від 7 серпня 2019 р. №584/2019. URL: https://www.president.gov.ua/ documents/5842019-28949 (дата звернення: 10.08.2019).

7. Про внесення змін до деяких законодавчих актів України щодо виконання Плану дій щодо лібералізації Європейським Союзом візового режиму для України стосовно відповідальності юридичних осіб: Закон України в редакції від 26.04.2015 р. № 314-VII. URL: https://zakon.rada.gov.ua/laws/show/314-18 (дата звернення: 16.05.2019).

8. Mitford J. Kind and usual punishment. The Prison Business. New York : Alfred Knopf. 1975.347 p.

9. Чернышов Д. В Минюсте рассказали о том, как работают частные тюрьмы. Espreso.tv. Новости. Общество. 19 июня, 2018. URL: https://ru.espreso.tv/news/ 2018/06/19/v (дата звернення: 10.07.2019).

10. Кримінально-виконавчий кодекс України: Закон України від 11.07. 2003 р. № 1129-IV. Відомості Верховної Ради України, 2004, № 3-4, ст. 21. Редакція від 04.11.2018, підстава 2581-VIII. URL: https://zakon.rada.gov.ua/laws/show/1129-15 (дата звернення: 10.07.2019).

11. Конституція України: Прийнята на п’ятій сесії Верховної Ради України 28 червня 1996 р. Київ : Преса України, 1997. 80 с.

\section{References}

1. Utevskij, B. S. (1957). Voprosy teorii ispravitelno-trudovogo prava i praktika ego primeneniya. Sovetskoe gosudarstvo i pravo, 12, 129-132 [in Russian].

2. Tkachevskij, Yu. M. (1998). Sootnoshenie ugolovnogo i ugolovno-ispolnitelnogo zakonodatelstva. Vestnik Moskovskogo universiteta. Seriya «Pravo», 2, 12-24 [in Russian].

3. Stepanyuk, A. (Red.). (2005). Kriminalno-vikonavche pravo Ukrayini: pidruchnik dlya studentiv yuridichnih specialnostej vishih navchalnih. Harkiv : Pravo [in Ukrainian].

4. Tolkachenko, A. (Otv. Red). (2004). Ugolovno-ispolnitelnoe pravo: kurs lekcij. Sankt-Peterburg : Izd-vo «Yurid. centr. Press» [in Russian].

5. Denisova, T. A. (2008). Kriminalne pokarannya: zavdannya i funkciyi, praktika zastosuvannya. Pravova sistema Ukrayini: istoriya, stan ta perspektivi: u 5 t. T. 5: Kriminalnopravovi nauki. Aktualni problemi borotbi zi zlochinnistyu v Ukrayini /Za zag. red. V. V. Stashisa. Harkiv : Pravo [in Ukrainian].

6. Polozhennya pro Komisiyu z pitan pravovoyi reformi: Ukaz Prezidenta Ukrayini vid 7 serpnya 2019 r. №584/2019. URL: https://www.president.gov.ua/documents/ 5842019-28949 (accessed: 10.08.2019) [in Ukrainian].

7. Pro vnesennya zmin do deyakih zakonodavchih aktiv Ukrayini shodo vikonannya Planu dij shodo liberalizaciyi Yevropejskim Soyuzom vizovogo rezhimu dlya Ukrayini stosovno vidpovidalnosti yuridichnih osib: Zakon Ukrayini v redakciyi vid 
26.04.2015 r. № 314-VII. URL: https://zakon.rada.gov.ua/laws/show/314-18 (accessed: 16.05.2019) [in Ukrainian].

8. Mitford, J. (1975). Kind and usual punishment. The Prison Business. New York : Alfred Knopf [in English].

9. Chernyshov, D. (2018) V Minyuste rasskazali o tom, kak rabotayut chastnye tyurmy. Espreso.tv. Novosti. Obshestvo, 19 iyunya URL: https://ru.espreso.tv/news/ 2018/06/19/v (accessed: 10.07.2019) [in Russian].

10. Kriminalno-vikonavchij kodeks Ukrayini: Zakon Ukrayini vid 11.07. 2003 r. № 1129-IV. Vidomosti Verhovnoyi Radi Ukrayini, 2004, № 3-4, st. 21. Redakciya vid 04.11.2018, pidstava 2581-VIII. URL: https://zakon.rada.gov.ua/laws/show/1129-15 (accessed: 10.07.2019) [in Ukrainian].

11. Konstituciya Ukrayini: Prijnyata na p'yatij sesiyi Verhovnoyi Radi Ukrayini 28 chervnya 1996 r. (1997). Kiyiv : Presa Ukrayini [in Ukrainian].

T. Denysova, Doctor of Law, Professor, Honored Lawyer of Ukraine, Member of the Presidium of the Ukrainian Criminal Law Association

ORCID ID: 0000-0003-4346-4502

\section{Is it necessary to modernize the criminal-executive legislation?}

The article identifies the problems, which testify that it is necessary to modernize the criminal law in the framework of the large-scale legal reform implementation. It is noted that the modern criminal law and criminal-executive legislation are still in the formation stage, despite the Criminal and CriminalExecutive Codes of Ukraine were adopted after proclaiming the independence of our country.

The criminal law and criminal-executive policy issues are considered. The big arsenal of measures of the influence of the criminal law and criminal-executive law on offenders is pointed out. In accordance with the requirements of the current criminal policy, the criminal deeds list is provided, as well as the type of sanctions and the order of enforcement of sentences are established. First of all, it is the definition of the main directions of the state policy, related to sentencing, enforcement of sentences, punishment effectiveness, functions of punishment, correlation of the essence, content, tasks and purpose of punishment, as well as the measures, which are alternative to imprisonment. At present, one of the important tasks in the criminal policy formulation is to find the optimal balance in using the persuasion, encouragement and coercion to ensure that the punishment corresponds to the gravity of the crime. Special attention is drawn to the fact that criminal-executive law and legislation are derived from the criminal law. The criminal-executive law rules perform the ancillary role in the punishment execution institute, which is defined in the substantive law.

The problems, which affect the quality of the criminal-executive legislation, are identified. Reformation of the Criminal-Executive Code of Ukraine should be implemented in different vectors, paying special attention to:

- quality of the law and its preventive nature;

- enforcement of sentences for criminal offenses; 
- execution of the criminal liability of legal entities;

- civil litigation institute;

- correction and re-socialization of convicts as the punishment purpose;

- private penitentiary establishments;

- impact of other sartorial legislations on the criminal-executive law.

It is emphasized, that in view of the complexity of the problems, changes of the ideological and practical paradigms, it is necessary to modernize the criminalexecutive legislation of Ukraine. Such work should be synchronous with the reformation of the Criminal Code of Ukraine. Such purpose cannot be successfully achieved, unless the scientific potential and the civil society institutions are involved. Besides, the maximum openness and sufficient material support are needed.

Keywords: enforcement of sentences; criminal law; criminal-executive legislation; modernization; criminal-executive service; probation.

Надійшла до редакції 02.08.2019 